\title{
Inflammatory fibroid polyp causing colocolic intussusception in an infant
}

\author{
MARK WALTON MD FRCSC, JUAN BASS MD FRCSC, BLAIR CARPENTER MD FRCPC
}

M WALTON, J BASS, B CARPENTER. Inflammatory fibroid polyp causing colocolic intussusception in an infant. Can J Gastroenterol 1994;8(4):246248. A three-month-old infant presented to the emergency department with a $24 \mathrm{~h}$ history of irritability and lesion prolapsing intermittently per anus. The child had a six-week history of blood and mucus per rectum. Digital rectal examination and sigmoidoscopy revealed what appeared to be a large mobile polypoid lesion arising from the rectum. Plans for excision were made. Sigmoidoscopy performed the following morning failed to demonstrate any lesion in the rectum or sigmoid. Barium enema demonstrated a sessile 'apple core type' lesion in the descending colon. Segmental resection of the descending colon with end-to-end anastomosis was performed. Pathological examination of the resected bowel demonstrated features consistent with an inflammatory fibroid polyp. This case appears to be unique because of the young age of the patient, its unusual location and its presentation as an intermittent colocolic intussusception.

Key Words: Colocolic intussusception, Inflammatory fibroid polyp

\section{Polype fibroïde inflammatoire responsable d'une intussusception chez un nourrisson}

RÉSUMÉ : Un nourrisson de trois mois est amené à l'urgence pour une irritabilité persistante depuis 24 heures et un prolapsus anal intermittent. L'enfant a évacué du sang et du mucus par le rectum durant six semaines. Le toucher rectal et la sigmoïdoscopie ont révélé une lésion polypoïde apparemment volumineuse et mobile. Une ablation est prévue. La sigmoïdoscopie effectuée le lendemain matin n'a démontré aucune lésion au rectum ou au sigmoïde. Le lavement baryté a révélé une lésion sessile en «coeur de pomme» au niveau du côlon descendant. Une résection segmentaire du côlon descendant, avec anastomose termino-terminale a été effectuée. L'examen pathologique de la portion réséquée a révélé des caractéristiques propres à un polype fibroïde inflammatoire. Ce cas semble unique à cause du jeune âge du patient, de sa localisation inhabituelle et de sa présentation sous forme d'intussusception colocolique intermittente.

Departments of Surgery and Pathology, Children's Hospital of Eastern Ontario, University of Ottawa, Ottawa, Ontario

Correspondence and reprints: Dr Juan Bass, Department of Surgery, Children's Hospital of Eastern Ontario, 401 Smyth Road, Ottawa, Ontario K1H 8L1. Telephone (613) 737-2799, Fax (613) 738-4840

Received for publication August 13, 1993. Accepted December 10, 1993
TNFLAMMATORY FIBROID POLYP WAS first described by Vanek (1) as "gastric submucosal granuloma with eosinophilia”. Similar lesions have been described in the small bowel and colon (2-5). The term inflammatory fibroid polyp was first proposed by $\mathrm{Hel}$. wig and Ranier (6) for gastric polyps and has gained acceptance for similar lesions throughout the gastrointestinal tract.

Most cases reported have been in the adult population. We report a case of an inflammatory fibroid polyp presenting in a three-month-old infant.

\section{CASE PRESENTATION}

A three-month-old male presented to the emergency department with a $24 \mathrm{~h}$ history of irritability and intermittent prolapse of a lesion per anus. The child had a six-week history of blood and mucus per rectum. A lesion prolapsing intermittently per anus was seen. Digital rectal examination revealed what appeared to be a large mobile polypoid lesion. A rigid sigmoidoscopy was performed in the emergency department demonstrating a friable lesion in the rectum. The initial impression was that this polypoid lesion was arising from the rectum. Plan for removal of the polyp under general anesthesia the next morning was arranged. Sigmoidoscopy performed the following morning failed to demon- 


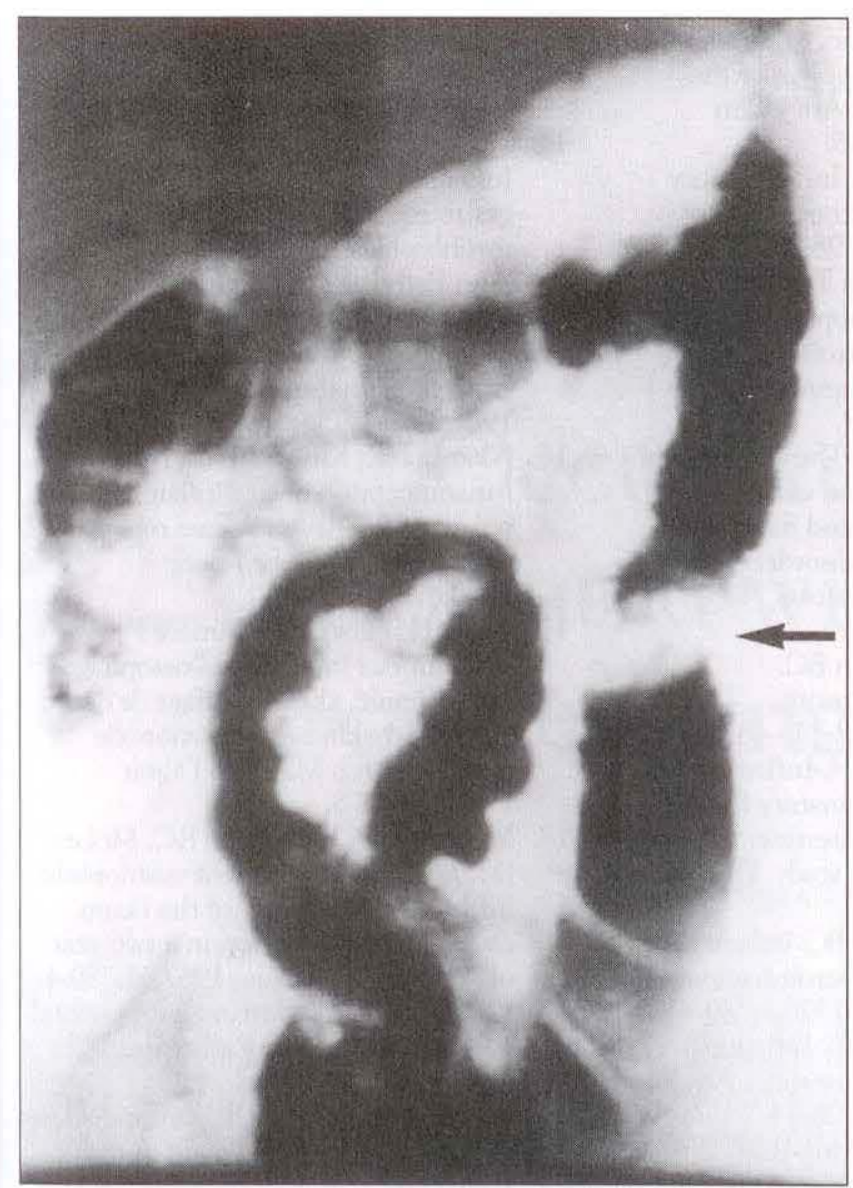

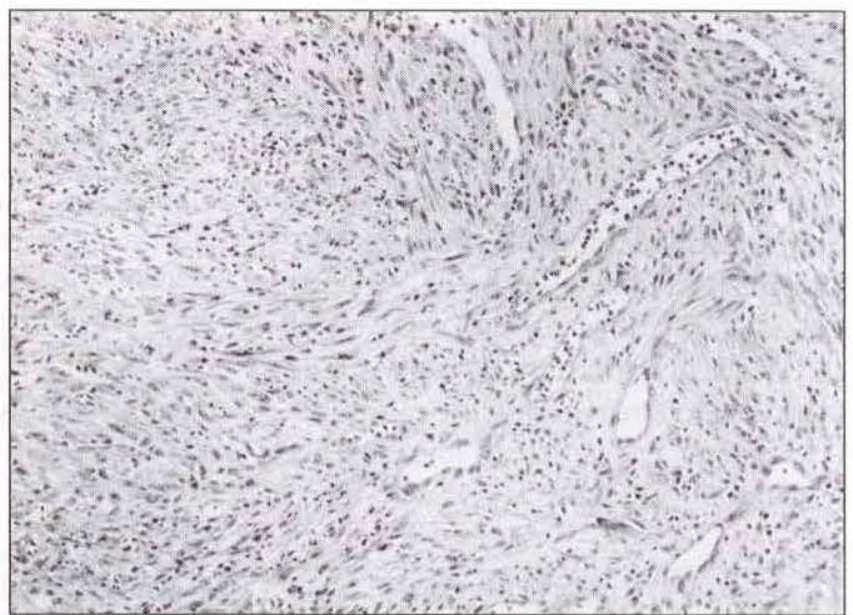

Figure 2) Representative section from colonic polyp shows the characteristic fibroblastic stroma with fascicles and whorls of proliferating fibroblasts, arborizing vessels and randomly distributed inflammatory cells, including eosinophils (trichrome x86)

Figure 1) Left Barium enema: 'apple core type' lesion in the descend-ing colon strate any lesion in the rectum or sigmoid.

Barium enema was then performed, demonstrating a sessile 'apple core type' lesion in the descending colon (Figure 1). It was clear that probably the air introduced during the sigmoidoscopy the previous night had reduced the bowel to its normal position. After mechanical bowel preparation, the patient underwent segmental resection of the descending colon with end-to-end anastomosis. Pathological examination of the resected bowel demonstrated features consistent with an inflammatory fibroid polyp (Figure 2).

Fourteen months postoperatively the child remains asymptomatic.

\section{DISCUSSION}

Inflammatory fibroid polyp is a rare benign lesion seen mostly in adults, generally occurring in the gastroduodenal area and small bowel. Histologically it is characterized by a fibrous polypoid lesion originating in the submucosa extending through the muscu- laris mucosae into the mucosa. It contains abundant inflammatory cells including eosinophils in various amounts. Associated mucosal ulceration is frequent. Although once believed to be associated with eosinophilic gastroenteritis $(7,8)$, it represents a separate entity of unknown etiology $(6,9,10)$. Peripheral blood shows no eosinophilia (11). Almost all lesions are focally ulcerated, likely secondary to the intraluminal location and intussusception of the polyp (12). The stroma contains concentrically arranged fibroblast and is infiltrated by eosinophils to a varying degree, often to a great extent. Occasional mitoses are found; however, there is no atypia.

There is inflammatory granulation tissue infiltrating the submucosa and mucosa at the margin of the polyp. Granulomas per se are not a component of inflammatory fibroid polyps. The granulation tissue on the floor of the ulcer is often invasive as in nodular fasciitis. There is a striking similarity in light microscopy and ultrastructural features, as well as biological behaviour between inflammatory fibroid polyps and some types of fibromatosis (13). Immunohistochemical study in some cases suggests a myofibroblastic origin for the proliferating cells $(13,14)$.

Adults, mean age of 48 years, form the majority of patients described in the literature (12). We could find only 12 cases of inflammatory fibroid polyp in children reported in the literature $(10,12,15-20)$. In six patients, it was located in the esophagus, ileum, jejunum, transverse colon and rectum, and in the remaining seven patients, the site was not specified. The youngest patient previously reported was two years old. We could not find any report of inflammatory fibroid polyp in children in the gastroduodenal area, the most common location in the adult population.

The polyp is obstructive (15) and presenting symptoms depend on the location of the lesion. Nonspecific symptoms include abdominal pain, vomiting, abdominal distension, gastro- 
intestinal bleeding and weight loss. Intussusception is almost always the presenting feature for lesions located in the small bowel (12). Duration of symptoms as long as 20 months has been described. However, $76 \%$ of the patients have symptoms for four weeks or less (12).

Recurrence has only been reported in an ileal lesion in a two-year-old child (18). Treatment is that of local resection and the prognosis is good.

ACKNOWLEDGEMENTS: The authors thank Dr Steven Rubin for reviewing this manuscript.

\section{REFERENCES}

1. Vanek J. Gastric submucosal granuloma with eosinophilic infiltration. Am J Pathol 1949;25:397-407.

2. Fenton F, Matz LR, Golinger D. Inflammatory fibroid polyp of the ileum: A case report. Pathology 1971;3:257-62.

3. Kerr WH, Mark JBD. Ileal intussusception in the adult due to inflammatory fibroid polyps. Surgery 1968;63:604-8.

4. McGee HJ. Inflammatory fibroid polyps of the ileum and cecum. Arch Pathol 1960;70:203-7.
5. Samter TG, Alstott DF, Kurlander GJ. Inflammatory fibroid polyps of the gastrointestinal tract. Am J Clin Pathol 1966;45:420-35.

6. Helwig EB, Ranier A. Inflammatory fibroid polyps of the stomach. Surg Gynecol Obstet 1953;96:355-67.

7. Ureles AL, Alschibaja T, Lodico D, et al. Idiopathic eosinophilic infiltration of the gastrointestinal tract, diffuse and circumscribed. Am J Med 1961;30:899-909.

8. Suen KC, Burton JD. The spectrum of eosinophilic infiltration of the gastrointestinal tract and its relationship to other disorders of angiitis and granulomatosis. Hum Pathol 1979;10:31-43.

9. Johnstone JM, Morson BC. Eosinophilic gastroenteritis. Histopathology 1978;2:335-48.

10. LiVolsi VA, Perzin KH. Inflammatory pseudotumors (inflammatory fibroid polyps) of the small intestine: A clinicopathological study. Dig Dis 1975;20:325-36.

11. Johnstone JM, Morson BC. Inflammatory fibroid polyp of the gastrointestinal tract. Histopathology 1978;2:349-61.

12. Shimer GR, Helwig EB. Inflammatory fibroid polyps of the intestine. Am J Clin Pathol 1984;81:708-14.

13. Navas-Palacios JJ, Colina-RuizDelgado $F$, Sanchez-Larrea MD, et al. Inflammatory fibroid polyps of the gastrointestinal tract: An immunohistochemical and electron microscopic study. Cancer 1983;51:1682-90.

14. Widgren S, Pizzolato GP. Inflammatory fibroid polyp of the gastrointestinal tract: possible origin in myofibroblast? A study of twelve cases. Ann Pathol 1987;7:184-92.

15. Blackshaw AJ, Levison DA. Eosinophililc infiltrates of the gastrointestinal tract. J Clin Pathol 1986;39:1-7.

16. Nkanza NK, King M, Hutt MSR. Intussusception due to inflammatory polyps of the ileum. A case report of 12 cases from Africa. $\mathrm{Br}$ J Surg 1980;67:271-4.

17. Welti H, Paradés B, Ganière P. Volumineux fibrome de l'oesophage ayant simulé, chez un enfant de douze ans, une dyskinésie avec anorexie mentale. Arch Mal App Digest 1960;49:592-8.

18. McGreevy P, Boberneck RC, McLeay JM, Miller FA. Recurrent eosinophilic infiltrate (granuloma) of the ileum causing intussusception in a two year old child. Pediatr Surg 1967;61:280-4.

19. Pollice L, Bufo P. Inflammatory fibroid polyp of the rectum. Pathol Res Pract 1984;17:508-12.

20. Samter TG, Alstott DF, Kurlander GJ. Inflammatory fibroid polyps of the gastrointestinal tract. A report of 2 cases, 2 occurring in children. Am ] Clin Pathol 1966;45:420-36. 


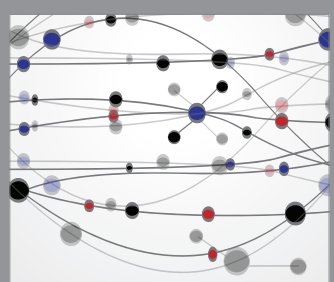

The Scientific World Journal
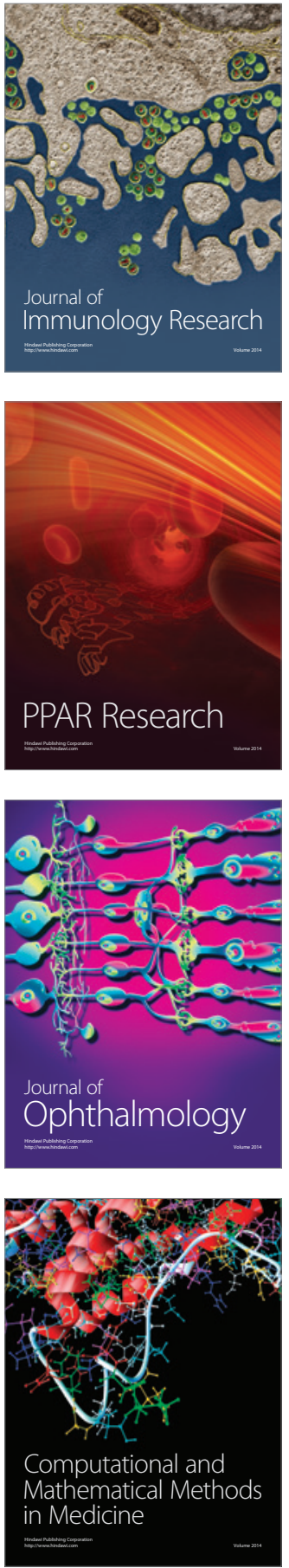

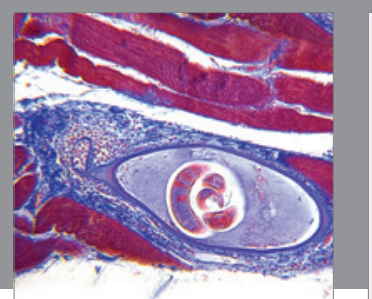

Gastroenterology Research and Practice

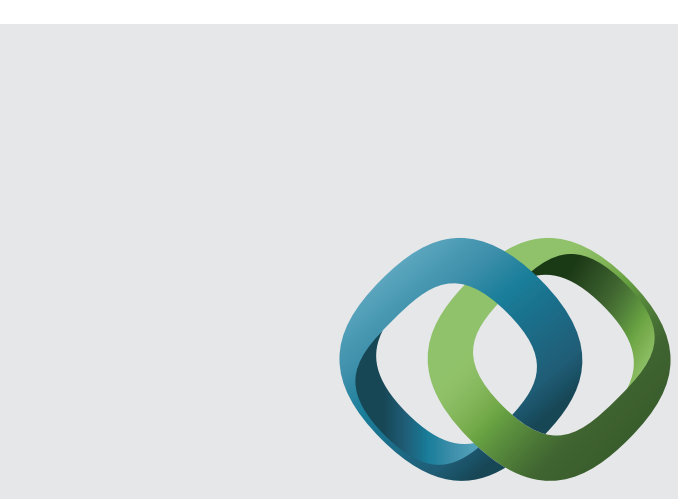

\section{Hindawi}

Submit your manuscripts at

http://www.hindawi.com
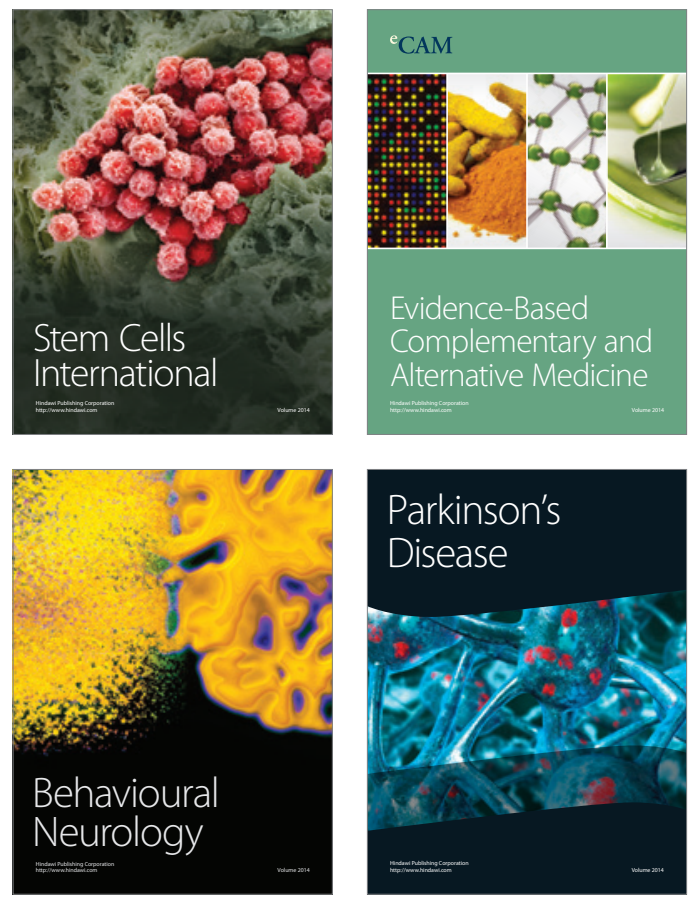
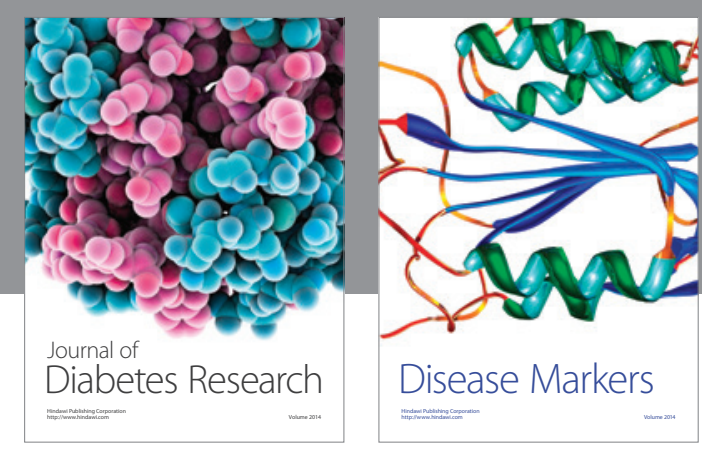

Disease Markers
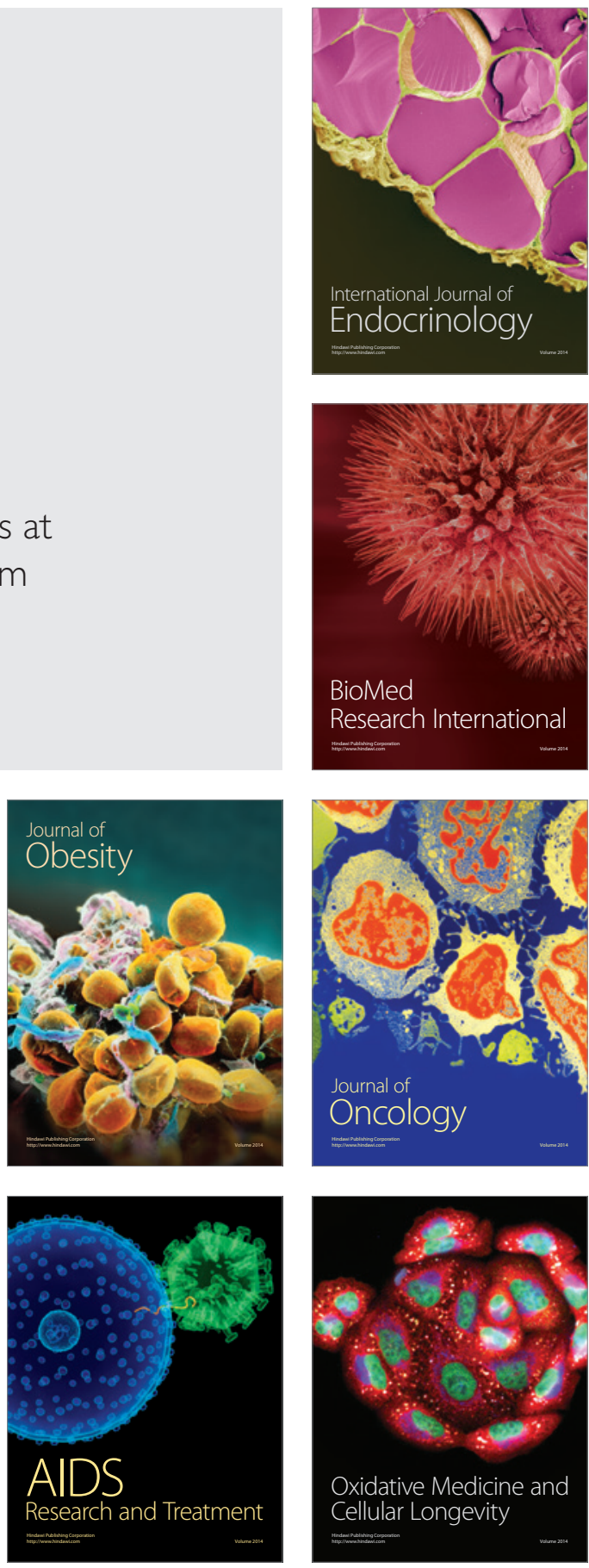